\title{
The Importance of Environmental Materials on Indonesian Language Learning
}

\author{
Ayu Puji Lestari \\ ayupujilestari310799@gmail.com
}

In environmental life, it has a very important role. Environmental materials can be linked to Indonesian language learning. In learning Indonesian, environmental material is very important, because by studying environmental material students will have a good understanding of environmental material, so that students have sensitivity and concern for the environment, especially the classroom environment when learning Indonesian.

The environment includes everything that is around us. According to Lai CS (in Ramadhan, et al, 2019) said that "environmental problems are inherently inseparable from environmental awareness, values, and attitudes of people. This encourages countries to start assessing environmental education ". Basically, environmental problems cannot be separated from environmental awareness, values, and people's attitudes. This encourages countries to start assessing environmental education. " One problem that often occurs is the cleanliness of the surrounding environment. People do not realize that their actions can damage the environment. According to Cokcaliskan and Celiko (in Ramadan at al, 2019) individuals should be encouraged not to view the environment as something that must be exploited for their purposes, but as a valuable asset that must be protected for human survival.

According to Buldur and Omeroglu (in Ramadhan, et al, 2019) teachers play an important role in teaching environmental education and fostering student awareness about the environment. In addition, Begman B, G (in Ramadhan et al, 2019), related to that the teacher also has an important role in teaching environmental material to students. Teachers must also develop students' abilities in understanding, criticizing, and participating rationally in any discourse about environmental problems. According to Jacobs G.M and Cates K (in Ramadhan et al, 2019), the purpose of environmental education is to make students participate in protecting the environment, to make students participate in protecting the environment.

Environmental materials taught in schools and colleges are policies of educational experts that need to be praised, by studying environmental materials from an early age, both from schools and colleges can foster awareness of the importance and preservation of their 
respective environments. According to Unyar and Ensar (in Ramadhan et al, 2019) the use of environmental themes in text learning can trigger students 'interest in learning language and can implicitly increase students' knowledge of the environment. In addition, (Ramadhan, et al, 2019) also argued that environmental education is important to increase student attitudes and awareness of the environment.

According to Obasoro, Olinloye, and Ilensami (in Ramadhan et al, 2019), students need to have good experience in understanding and coping with every global change and society's environment. According to Kollmuss A and Agyeman J, Schultz PW, Shriver C, Tabanico JJ, and Khazian AM, Xehua Z, and Çokçaliskan H and Çelik Ö (in Ramadhan et al, 2019), so that students participate in protecting the environment, it is important to develop knowledge about environment, environmental awareness and changes in behavior towards the environment

Based on the above problems, the author has distributed a questionnaire about the importance of environmental materials for Indonesian language learning aimed at undergraduate students from various departments, universities and also gender. The research conducted was to make ten questions about the importance of environmental material in Indonesian in the form of a google form questionnaire. The results obtained from the study are as follows. The first point, in learning Indonesian, environmental material is very important, which states strongly agree $(57.4 \%)$, agree $(42.6 \%)$, disagree $(0 \%)$ and disagree $(0 \%)$. The second point, in learning Indonesian, materials with the theme of the environment are a strategy to increase vocabulary, which states agree (63\%), strongly agree (37\%), disagree $(0 \%)$ and disagree $(0 \%)$. The third point, in learning Indonesian the teacher invites students to love the surrounding environment more, which states strongly agree $(57.44 \%)$, agree $(42.6 \%)$, disagree $(0 \%)$ and disagree $(0 \%)$. The fourth point, environmental material in Indonesian language learning is related to the use of Indonesian in everyday life, which states strongly agree $(52.8 \%)$, agree $(47.2 \%)$, disagree $(0 \%)$ and disagree $(0 \%)$. The fifth point, in learning Indonesian, environmental material is related to the social environment, the natural environment, and the environment, which states strongly agree $(51.9 \%)$, agree $(48.1 \%)$, disagree $(0 \%)$ and disagree $(0 \%)$. The sixth point, environmental material in Indonesian language learning aims at the occurrence of a process of communication or interaction between students and the environment, which states strongly agree (57.4\%) agree $(42.6 \%)$, disagree $(0 \%)$ and disagree $(0 \%)$. The seventh point, when learning Indonesian, the 
teacher must invite students to protect and preserve the environment, who strongly agree $(59.3 \%)$, agree $(40.7 \%)$, disagree $(0 \%)$ and disagree $(0 \%)$. The eighth point, material about the

environment in Indonesian language learning makes students care about environmental cleanliness, who strongly agree $(50 \%)$, agree $(50 \%)$, disagree $(0 \%)$ and disagree $(0 \%)$. The ninth point, the advantage of having environmental material in Indonesian language learning is that students can respect and protect the environment well, who agree (59.3\%), strongly agree $(40.7 \%$, disagree $(0 \%)$ and disagree $(0) \%)$ And the last point, environmental material in Indonesian language learning is highly recommended for students, who strongly agree (50\%), and agree $(50 \%)$, disagree $(0 \%)$ and disagree $(0 \%)$.

Based on the results of the author's research above, it can be concluded that environmental material in Indonesian language learning is indeed very important. This can be seen from the answers of respondents who stated positively about the importance of environmental materials in Indonesian. With the existence of environmental material students will increasingly protect and preserve their environment, foster a sensitive attitude to the situation and conditions of the surrounding environment and build honest, disciplined, empathetic, and optimistic and religious characters. This paper aims so that the community and students can protect the environment.

\section{Reference}

Bergman, B.G. (2016). Assessing impacts of locally designed environmental education projects on students' environmental attitudes, awareness, and intention to act Environmental Education Reseach 22(4) 480-503

Buldur, A. and Ömeroglu, E. (2018). An examination of the relationship between preschool children's and their teacher' attitute and awareness towards the environment Journal of Education and Learning 7(2) 221-9

Cokcaliskan H and Celiko (2017). Investigation of pre-service classroom teacher's awareness and attitudes International Electrinic Journal of Environmental Education 7(2) $73-83$

Çokçaliskan H and Çelik Ö (2017). Investigation of pre-service classroom teachers’ 
environmental awareness and attitudes International Electronic `Journal of Environmental Education $773-83$

Jacobs G M and Cates K.(2012). Global education in second language and teaching. International Journal of Physical and Social Sciences 2 1-22

Kollmuss A and Agyeman J. (2002). Mind the gap: Why do people act enviconmentally and what are the barriers to pro-environmental behavior Environmental Education Research 239-60

Lai, C.S. (2018). A study of fifth graders environmental learning outcomes in Taipel International Journal Of Research In Education and Science 4(1) 252-61

Ramadhan, S., Sukma, E., \& Indriyani, V. (2019). Environmental education and disaster mitigation through language learning. IOP Conference Series: Earth and Environmental Science, 314

Schultz P W, Shriver C, Tabanico J J and Khazian A M. (2004). Implicit connections with nature Journal of Environmental Psychology 24 (1) 31-42

Xuehua Z.(2004) An overview of the environmental knowledge system for elementary school students Chinese Education and Socie 37(4) 45-7 